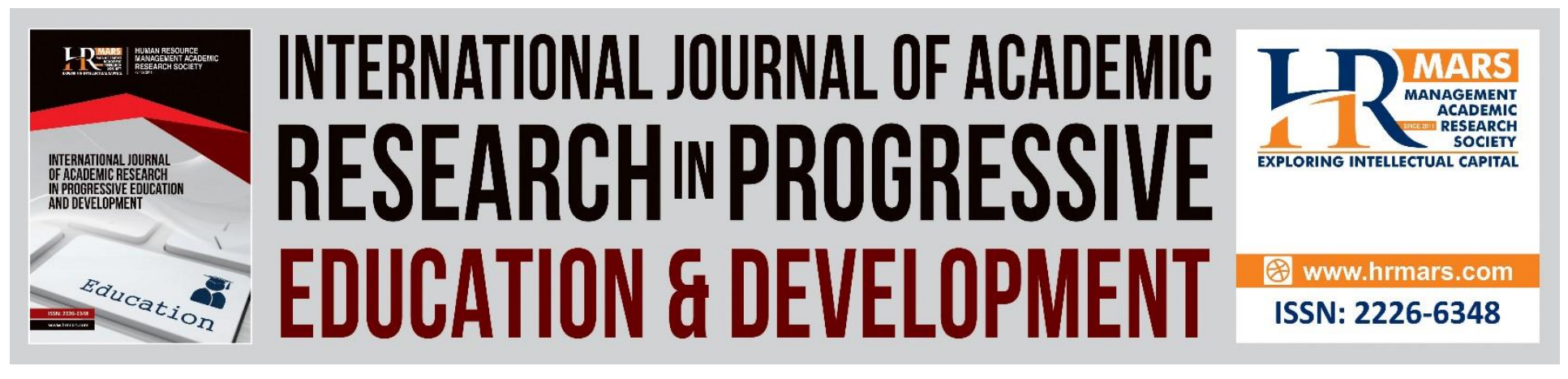

\title{
The Effects Of Collaborative Mobile Learning Using Edmodo Among Economics Undergraduates
}

\author{
Khoo Yin Yin, Rohaila Yusof, Stanley Yap Peng Lok, Zainzam Zakariya
}

To Link this Article: http://dx.doi.org/10.6007/IJARPED/v7-i3/4283

DOI: $10.6007 /$ IJARPED/v7-i3/4283

Received: 03 June 2018, Revised: 18 June 2018, Accepted: 03 July 2018

Published Online: 20 July 2018

In-Text Citation: (Yin, Yusof, Lok, \& Zakariya, 2018)

To Cite this Article: Yin, K. Y., Yusof, R., Lok, S. Y. P., \& Zakariya, Z. (2018). The Effects Of Collaborative Mobile Learning Using Edmodo Among Economics Undergraduates. International Journal of Academic Research in Progressive Education and Development, 7(3), 40-47.

\section{Copyright: (c) 2018 The Author(s)}

Published by Human Resource Management Academic Research Society (www.hrmars.com)

This article is published under the Creative Commons Attribution (CC BY 4.0) license. Anyone may reproduce, distribute, translate and create derivative works of this article (for both commercial and non-commercial purposes), subject to full attribution to the original publication and authors. The full terms of this license may be seen

at: http://creativecommons.org/licences/by/4.0/legalcode

Vol. 7, No. 3, July 2018, Pg. 40 - 47

http://hrmars.com/index.php/pages/detail/IJARPED

JOURNAL HOMEPAGE

Full Terms \& Conditions of access and use can be found at http://hrmars.com/index.php/pages/detail/publication-ethics 


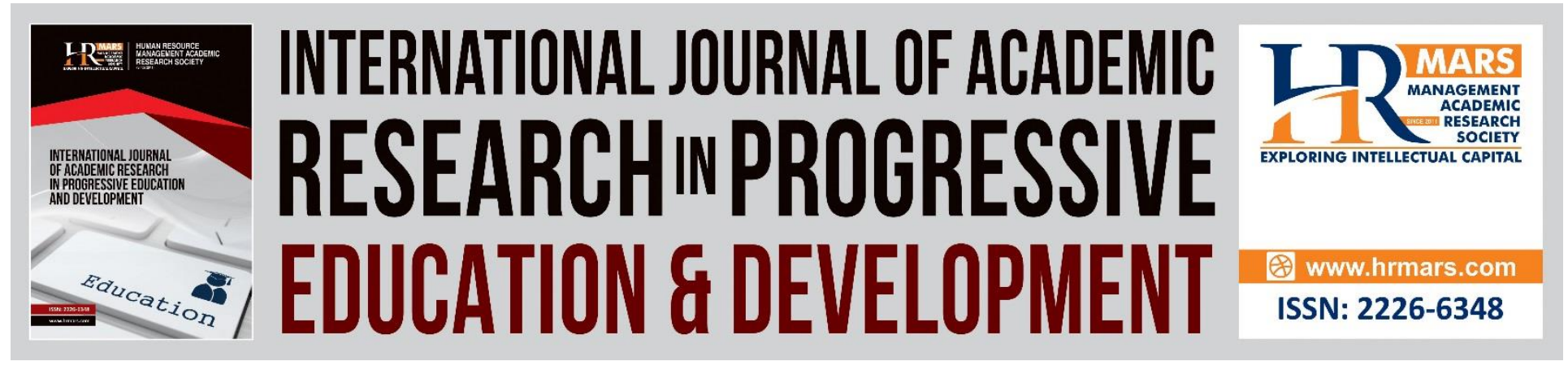

\title{
The Effects Of Collaborative Mobile Learning Using Edmodo Among Economics Undergraduates
}

\author{
Khoo Yin Yin \\ Universiti Pendidikan Sultan Idris, Malaysia \\ Email:khoo@fpe.upsi.edu.my \\ Rohaila Yusof \\ Universiti Pendidikan Sultan Idris, Malaysia \\ Stanley Yap Peng Lok \\ Segi University Malaysia \\ Zainzam Zakariya \\ Universiti Pendidikan Sultan Idris, Malaysia
}

\begin{abstract}
The purpose of this paper is to examine the effects of mobile learning towards undergraduates' performance and interest in Malaysia. A quasi-experimental method was employed in this study. A total of 112 respondents were employed as samples. A random sampling technique was employed in this study. The samples were divided into experimental group and control group. The findings indicated that Edmodo contributes significant positive effects towards students' performance, interest and collaborative problem solving skills. Further research will consider to unlock the effects of Edmodo mobile learning in other courses.

Keywords: Mobile Learning, Performance, Quasi-experimental

\section{Introduction}

The transformation of the learning style from face-to-face to the online learning environment has led to the rapid increase of the usage of mobile learning in Malaysia. Mobile learning has become popular among undergraduates due to the popularity of the mobile phone among the young generation (Suominen, Hyrynsalmi \& Knuutila, 2014). However, little is known about the pedagogical effects of collaborative learning in this area. Moreover, educators should be ready in terms of developing or utilising mobile learning in teaching and learning. Since there is limited research literature on mobile learning in Malaysia, this research gap has to be filled.
\end{abstract}


Since the users of social media have increased tremendously among the younger generation, there is a developing trend in online learning to provide increased interaction and engagement in undergraduate education. Therefore, in this study a new learning method will be developed and explored to enhance economics concept among undergraduate students. However, effective learning only occurs when students make a conscious decision to learn and are ready to engage in the learning activities, especially collaborative learning that involves interaction among peers, lecturers and students.

Edmodo is a free, unrestricted and protected educational learning network among all the social networks (Kandappan, Jaykumar, \& Fukey, 2014). It has a similar function with Facebook. However, Edmodo has been designed slightly different from Facebook where it has a secure and private learning setting. It has provided a simple method for lecturers to create and maintain online classroom community as well as enable students to connect collaboratively with their peers anywhere and anytime. Edmodo also allows lecturers to form small groups in the virtual class. Students can communicate with others all over the world by using Edmodo through their hand phone or laptop.

The findings of Heijlities, Van Grog, Leppoink and Pass (2014) indicated that the economics graduates did not have deep understanding of the economics concept and reasoning ability as compared to the normal graduates. They also found that most of the economics classes only emphasised on mathematics calculation and techniques to the detriment of economics reasoning ability. In fact, prior research (Cash, Letargo, Graefeer \& Jacobs, 2017) has shown that undergraduates' learning can be problematic particularly with respect to large classes, students' participation, limited teaching time and lecturers' attitude. One of the common problems was limited opportunities for students' participation during discussion as there was a tendency for lecturers to tell them the answers instead of allowing students to develop their own answers (Svinicki \& McKeachie, 2014). This happened as most of the lecturers had limited time in one day due to their heavy workload. Therefore, to give the students the answers was the fastest way to complete their task. However, the lecturers did not realise that they had duplicated and implemented the pedagogy from the traditional teaching in the online collaborative learning environment. As a result, an effective mobile collaborative learning approach needs to be implemented in the online learning environment.

\section{Literature Review}

This study was based on the theory of Communities of Practice (CoP) (Wenger, 1998) that provided a conceptual framework for the online and blended learning environments in higher education.

Wenger focused on the idea of CoP and how social resources influence students' learning. In addition, Wenger developed the concept of CoP by presenting that learning is applicable to various contexts. CoP has become one of the most widely cited and influential conceptions of social learning.

Wenger, Trayner, and de Laat (2011) defined CoP as a "learning partnership among people who find it useful to learn from and with each other about a particular domain" in their current study. However, Smith, Hayes and Shea (2017) argued that certain areas in this review should be 
Vol. 7, No. 3, July 2018, E-ISSN: 2226-6348 @ 2018 HRMARS

considered for the future. One of the aspects that is related to this study is making the nature of engagement visible in order to help the learners learn how to participate in meaningful learning.

\section{Model of Collaborative Online Learning (COL)}

There are several models of collaborative online learning. This paper only focuses on the research conducted by Harasim (2012) who stated that in collaborative online learning, the students are encouraged and supported to work together to create knowledge. The students can explore ways to innovate and to seek the conceptual knowledge needed to solve problems rather than recite what they think as the right answer.

\section{Core design principles of Collaborative Online Learning}

Harasim (2012) emphasises the importance of the three key phases of knowledge construction through discourse, which include:

- $\quad$ idea generating: Idea generating can be done through brainstorming activities.

- $\quad$ idea organising: Students compare, analyse and categorise the different ideas through discussion in groups.

- $\quad$ intellectual convergence: This level can be achieved through the joint construction of the idea or piece of work into an essay or assignment.

The important factor is in the COL model, and discussion forums are the core component of the teaching. Other resources and text books are chosen to support the discussion. The students will engage in the online discussion setting and instructors will use a CLO approach in the form of learning management systems for convenience which is different from the traditional didactic teaching when conducted online.

\section{The Advantages of Using Edmodo in Learning}

Prior research stated that Edmodo has a great benefit in improving students' performance (Gomez, Magrenan and Orcos, 2015). Students showed their learning interest when using Edmodo. They used Edmodo outside the classroom, anywhere and anytime. The findings of Kandappan, Jaykumar, \& Fukey (2014) showed that students' prefer to use Edmodo as a discussion platform. Edmodo promoted students' learning interest. The results also showed that students benefitted from participating in the Edmodo groups as a community which allowed them to communicate with teachers and peers. This research also indicated that the participation in Edmodo enhanced students' collaborative learning skills.

Even though, there are countless research have been done on e-learning, however Edmodo is a new area yet to be explored. Prior studies about Edmodo basically is focus on Mathematic courses, none of the research has been carried out on Economics courses.

\section{Methodology}

This study employed the quasi experimental pre-post design. The study involved 112 undergraduates in a Malaysia public university. The sampling technique used in this study was a 
Vol. 7, No. 3, July 2018, E-ISSN: 2226-6348 @ 2018 HRMARS

simple random sampling by using a random table number. The samples were divided into two groups (experimental group and control group).

\section{Instruments}

A set of 30-item performance test and 30-item questionnaire were used as instruments of this study. The questionnaire and performance assessment were constructed by the researchers based on the Theory of Collaborative Online Learning. A pilot test was carried out to examine the validity and reliability of the instruments before carrying on the actual research. A total of 30 students in a university who were not going to participate in the actual study were taught in the same syllabus and same teaching method.

A team of experts was assigned to establish the content validity of the questionnaire and the performance assessment. The reliability of the performance was estimated by engaging the tests of Cronbach Alpha. This was done by appointing two distinguished and experienced examiners to check each item. The reliability of the questionnaire was calculated by the Cronbach alpha coefficient value .884. According to Sekeran and Bougie (2010), an instrument with the coefficient of 0.70 or above has a high reliability standard. Since the findings are in line with the benchmark, hence, all the items are acceptable and reliable.

\section{Research Procedures}

A training session was carried out with the lecturers and students before using Edmodo with collaborative problem solving in the actual study. The training included training the lecturers' and students' relevant skills of using the new learning platform.

The Collaborative Problem Solving took ten weeks to complete. The questionnaire was given to the students before and after the intervention. The students could work collaboratively in groups of four for their discussion. However, they had to post their views individually. The learning materials were sent to the students through Edmodo every week with different topics.

\section{Results}

The findings of the study indicated that the experimental group outperformed the control group. The results are illustrated in Table 1.

Table 1

Mean Score for Pre-Post Test of Performance, Interest and Collaborative Problem Solving Skills

\begin{tabular}{cccccc}
\hline & \multicolumn{2}{c}{$\begin{array}{c}\text { Experimental group } \\
(\mathbf{N}=\mathbf{5 6})\end{array}$} & \multicolumn{2}{c}{$\begin{array}{c}\text { Control group } \\
(\mathbf{N}=\mathbf{5 6})\end{array}$} & $\mathbf{N}$ \\
& Pretest & Posttest & Pretest & Posttest & \\
\hline Performance & 43.2134 & 79.4643 & 44.5805 & 75.3929 & 56 \\
Interest & 2.7694 & 4.1038 & 1.9918 & 3.6185 & 56 \\
Collaborative & 2.6805 & 3.9811 & 2.1784 & 3.8374 & 56 \\
problem solving & & & & & \\
\hline
\end{tabular}


Vol. 7, No. 3, July 2018, E-ISSN: 2226-6348 @ 2018 HRMARS

Students' performance was not much different in the pretest for the experimental group ( mean $=43.2134$, standard deviation $=10.256$ ) as compared to the control group (mean=44.5805, standard deviation=11.347). However, the experimental group outperformed (mean $=79.4643$, standard deviation $=9.4079$ ) the control group in students' performanance during the posttest.

In addition, the analysis showed that the mean score for students' interest in the pretest towards Edmodo for the experimental group (mean $=2.7694$ ) was slightly higher than the control group ( $m e a n=1.9918$ ). However, the findings indicated that the experimental group (mean=4.1038) outperformed the control group (mean=3.6185). On the other hand, the pretest mean for the experimental group in collaborative problem solving skills was similar with the control group (mean $=2.1784$ ) whereas, the experimental group (3.9811) scored higher mean in the collaborative problem solving skills as compared to the control group (3.8474) during the posttest.

\section{Discussion and Conclusion}

Edmodo collaborative mobile learning showed a significant result in performance, interest and collaborative problem solving skills. The major findings of this study showed that Edmodo collaborative mobile learning in experimental group outperformed than control group in students' performance. Gomez, Magrenan and Orcos (2015) and Végh, Nagy, Zsigmoid \& Elbert (2017) shared the same views that Edmodo enhanced students' academic performance because it could make the students felt the importance of the subject. Prior researches findings are similar with this study.

The findings of this study also indicated that the students in experimental group outperformed than the students in control group. This result also similar with prior research. Researchers believed that students who learn with Edmodo can enhance their learning interest (Charoenwet \& Christensen, 2016 ; Yanti, Setiawan, Nurhabibah \& Yannuar, 2018). The use of technology that supports the mobile learning environment could facilitate and provide opportunity for students to share ideas. Hence, students' learning interest can be increased.

The analysis in this study showed that the students in the experimental group outperformed than the students in control group. The research findings are in line with prior studies (Kandappan Balasubramaniana, Jaykumar \& Leena Nitin, 2014) which shows that Edmodo promotes students' engagement in collaborative discussion. In addition, students also enjoy learning with Edmodo. As a result, Edmodo can support blended learning that opens the opportunity for educators to transform the traditional school system (Hodge, 2015) to online learning. The students that participated in the process of finding knowledge using Edmodo felt that they made changes in the way they learned (Santa, 2014). Students also showed interest in learning when using Edmodo, and this finding is similar with previous study conducted (Taylor, 2015).

In conclusion, most of the students like to study with mobile phones because the phones have become part of their necessity. Mobile phone is portable, smaller and easier to carry as compared to laptop. It also provides students an opportunity to study anywhere and anytime. Overall the result showed that Edmodo contributes positive effects towards students' performance, interest 
INTERNATIONAL JOURNAL OF ACADEMIC RESEARCH IN PROGRESSIVE EDUCATION AND

DEVELOPMENT

Vol. 7, No. 3, July 2018, E-ISSN: 2226-6348 @ 2018 HRMARS

and collaborative problem solving skills. Further research can consider to unlocked the ability of Edmodo mobile learning in other courses.

\section{Acknowledgement}

This study was supported by UPSI internal educational grant (GPU khas) 2017-0251-107-01.

\section{References}

Cash,C. B., Letargo, J., Graefeer, S. P. \& Jacobs, S. R. (2017). An analysis of the perception and recources of large university classes. Life Science Education, 16(33), 1-12.

Charoenwet, S., \& Christensen, A. (2016). The effect of Edmodo learning network on students' perception, self-regulated learning behaviors and learning performance. Proceedings of the 10th International Multi-Conference on Society, Cybernetics and Informatics (IMSCI 2016).

Gomez, A., Magrenan A. A., \& Orcos, L. (2015). UX of social network Edmodo in undergraduate engineering students. International Journal of Interactive Multimedia and Artificial Intelligence, 3(4), 31-36.

Harasim, L. (2012). Learning theory and online technologies. Routledge.

Heijlities, Van Grog, Leppoink \& Pass (2014). Improving critical thinking: Effects of dispositions and

Instructions on economics students' reasoning skills. Learning and Instruction, 29, 31-42.

Hodge, A. (2015). Teachers' perceptions of an online social network as an instructional platform: The impact of an Edmodo-based professional development workshop. Doctoral Dissertations and Projects. Duquesne University.

Kandappan, B., Jaykumar, V., \& Fukey, L. N. (2014). A study on student preference towards the use of Edmodo as a learning platform to create responsible learning environment. Procedia Social and Behavioral Sciences, 144 (2014) 416 - 422.

Santa, B. (2014). A cultural historical activity theory perspective of teacher learning in the Edmodo math subject community. Unpublished thesis. University of California.

Sekeran, U., \& Bougie, R. (2010). Research methods for business: A skill building approach (5th ed). Chichester: John Willey \& Sons Ltd.

Svinicki, M., \& McKeachie, W. J. (2014). McKeachie's teaching tips: Strategies, research and theory for college and university teachers (14th ed.). USA: Cengage Learning.

Smith, S. U., Hayes, S., \& Shea, P. (2017). A critical review of the use of Wenger's Community of Practice (CoP) theoretical framework in online and blended learning research, 2000- 
INTERNATIONAL JOURNAL OF ACADEMIC RESEARCH IN PROGRESSIVE EDUCATION AND

DEVELOPMENT

Vol. 7, No. 3, July 2018, E-ISSN: 2226-6348 @ 2018 HRMARS

2014. Online Learning 21(1), 209-237.

Suominen, A., Hyrynsalmi, S., \& Knuutila, T. (2014). Young mobile users: Radical and individual. Not. Telemeties and Information, 31(2),266-281.

Végh V., Nagy Z. B., Zsigmond C., \& Elbert, G. (2017). The effects of using Edmodo in biology education on students' attitudes towards biology and ICT. Problems of Education in the 21st Century, 75 (5) 483-495.

Wenger, E. (1998). Communities of practice: Learning, meaning and identity. New York, NY: Cambridge University Press.

Wenger, E., Trayner, B., \& De Laat, M. (2011). Promoting and assessing value creation in communities and networks: A conceptual framework. The Netherlands: Ruud de Moor Centrum.

Yanti, Setiawan, Nurhabibah \& Yannuar. (2018). Teacher's Perception about the use of elearning/Edmodo in educational activities. IOP Conference Series: Materials Science and Engineering. 2nd International Conference on Innovation in Engineering and Vocational Education, ICIEVE 2017, 306 (1). 